\title{
Inflation Targeting and Exchange Rate Volatility in Emerging Markets
}

\author{
René Cabral \\ EGADE Business School \\ Tecnológico de Monterrey \\ Ave. Rufino Tamayo, Garza García, NL, CP. 66269, Mexico. \\ E-mail: rcabral@itesm.mx \\ Tel.: +52-81-8625-6148 and fax: +52-81-8625-6095. \\ Francisco G. Carneiro \\ The World Bank \\ 1818 H Street, NW, Washington DC 20433, USA \\ Email: fcarneiro@worldbank.org \\ Tel: +1-202-473-0360 \\ André Varella Mollick \\ Department of Economics and Finance \\ University of Texas Rio Grande Valley \\ 1201 W. University Dr., Edinburg, TX 78539-2999, USA \\ E-mail: andre.mollick@utrgv.edu \\ Tel.: +1-956-665-7136 and fax: +1-956-665-5020.
}

Keywords: emerging market economies, exchange rate, financial crisis, inflation targeting.

JEL classification: E31, E43, E52, E58, F33. 


\section{Introduction}

Over the last 35 years or so, the world economy has witnessed a plethora of phenomena. Of notice, one could quote the Great Moderation of the 1980s and 1990s and the Global Financial Crisis of 2008-09. The Great Moderation is illustrated by the dramatic fall in macroeconomic volatility in the United States and many other industrialized economies starting in the early to mid-1980s. During the Great Moderation period, central banks followed a policy rule which optimized their own country's domestic macroeconomic performance, setting up policies aiming at long-run price stability, and moving away from discretionary policies (see Oudiz and Sachs, 1984; and Taylor, 1985 and 2013).

In this context, as part of the policy framework that was characteristic of the Great Moderation period, many industrialized economies started using inflation targeting (IT) regimes. Central banks in countries that have adopted IT tend to determine monetary policy based on output and price fluctuations from their targets; i.e., central banks will be following "Taylor rules". The IT approach became more explicit with the strategies adopted in the early 1990s by a number of pioneering central banks, including the Reserve Bank of New Zealand, the Bank of Canada, the Bank of England, the Bank of Sweden, and the Reserve Bank of Australia. Over the past 20 years or so, variants of the IT framework have proliferated in emerging market economies, including Brazil, Chile, Israel, the Republic of Korea, Mexico, South Africa, and in a few transition economies such as the Czech Republic, Hungary, and Poland (Bernanke, 2003). The impact of IT on price stability in industrialized economies has been broadly addressed in the literature and there has been growing interest in understanding the effects of IT on output growth performance in emerging market economies.

As argued in the 2014 World Development Report (Risk and Opportunity - Managing Risk for Development), high inflation can negatively affect the saving and investment decision of households 
and firms and, as a consequence, lead to slower economic growth and hurt disproportionally the poor and the more vulnerable (World Bank, 2014). The literature on IT shows that IT adopters have been largely able to deliver low and stable inflation rates (see Mishkin and Schmidt-Hebbel, 2007a). As argued by Mishkin (2004), the success of the IT approach rests on an improved understanding of the monetary transmission channels and on three strong institutional factors that include: (a) a clear mandate to and commitment by central banks to maintain price stability; (b) central bank independence from political interference; and (c) greater central bank accountability to meet the target. In addition to that, Eichengreen et al. (1999) argue that a successful IT regime will have to meet a few pre-conditions, including (i) a well-developed technical infrastructure at the central bank to do inflation forecasting and modeling; (ii) a proper economic structure in the country where prices must be deregulated, the economy is mostly immune to commodity price fluctuations and not dollarized; and (iii) a healthy financial system so that the IT regime does not generate potential conflicts with financial stabilization objectives. For countries that do not meet these pre-conditions, Laurens et al. (2015) recommend the adoption of transitional arrangements before a full-fledged IT regime can be adopted. These interim arrangements would include the development of economic analysis capacity and a forward-looking approach to monetary policy, with interest-rate focused operating procedures, to achieve inflation objectives.

With this background, this paper reexamines the interactions between interest rates (the central bank policy variables) and exchange rates in emerging market economies (EMEs) using the IT framework. Since floating exchange rate mechanisms have become increasingly more prevalent in emerging markets, it is worthwhile reconsidering issues arising from studies connecting interest rates to exchange rates. By the ex-ante uncovered interest parity (UIP) condition in international finance, higher yielding currencies are expected to depreciate against the (foreign) lower paying counterpart. 
In practice, however, this condition is often violated and confirms the theoretical notion that exchange rates are determined by much more than interest rate differentials. Flood and Rose (2002) investigate this for a period of turbulence in financial markets and conclude that UIP performed relatively better during the crisis of the 1990s than other times. Frankel and Poonawala (2010) confirm that the UIP condition is not observed (ex-post) in emerging markets, although the rejection is not as severe as in industrial countries where a persistent negative term on the interest rate differentials coefficient has been documented: that is, positive interest rate differentials imply a stronger currency in industrial economies, all else constant.

In contributing to this growing literature, this paper investigates whether central banks in EMEs have been able to avoid exchange rate volatility better by using an active monetary policy than in the case of non-IT countries. This is an important question that may have implications for the policy rule followed by central banks in emerging market economies. Our empirical approach involves, in a first stage, using static and dynamic fixed effects models to assess whether the exchange rate in general is an important determinant in the reaction function of EMEs' central banks. We then use an alternative methodology, which allows us to control for potential endogeneity problems implicit in the specification of a Taylor rule not addressed in recent related literature. We do this by estimating our empirical model using system generalized method of moments (SGMM) techniques, which take into consideration the endogeneity of inflation, output, and the exchange rate in our model. A common finding in our estimations was the poor performance of the output gap as a determinant of the interest rate in every specification. This might be interpreted as an indication that, whether they target inflation or not, EMEs' central banks are more cautions today about inflation than about other developments in the economy, including exchange rate variations. We test the robustness of our results by 
partitioning the sample into inflation targeting and non-targeting countries, and then splitting the sample across time and dividing it into two periods, before and after the financial crisis.

The paper is organized as follows. Section 2 summarizes the recent evidence on the effects of IT focusing in particular on exchange rate volatility and the literature that has discussed the role of the exchange rate on the central bank reaction function in emerging market economies. Section 3 describes the data and their sources, and presents the empirical model we use in our econometric analysis. Section 4 discusses the empirical results, including the results of robustness checks. Section 5 concludes and presents a brief discussion of the policy implications associated with our findings.

\section{Inflation targeting and the exchange rate in emerging markets}

One of the main messages of the literature on inflation targeting is that it has been effective in achieving price stability without necessarily leading to a better output growth performance. Following the seminal work by Ball and Sheridan (2005), a number of studies assessed the impacts of IT on inflation and growth under similar methodologies and alternative approaches with a new emphasis on emerging markets. Batini and Laxton (2007) use a sample of 44 emerging markets to assess the effects of inflation targeting on diverse macroeconomic indicators directly and indirectly related to inflation performance. They find that IT provides a significant $4.8 \%$ reduction in average inflation, a $3.6 \%$ reduction in its volatility (standard deviation) and lower output gap volatility. On other dimensions indirectly related to inflation per se, they observe a reduction in the volatility of real interest rates and exchange rates.

Mishkin and Schmidt-Hebbel (2007a) employ a panel VAR analysis using emerging and industrial economies to assess IT effects on disinflation, exposition to shocks and monetary policy independence. Besides finding success in attaining price stability and a lower response to oil shocks, 
in terms of monetary policy independence they observe that domestic nominal interest rates are less exposed to foreign interest rate innovations. For emerging market economies, in particular, this achievement is more important and increasing when economies achieve stationary targets. For a more complete analysis of early assessments of IT effects, see also the works compiled by Loayza and Soto (2002), Fraga et al. (2003), and Mishkin and Schmidt-Hebbel (2007b).

More recently, a number of authors have discussed the effects of IT in different types of economies. Roger (2009) offers a comprehensive review, which starts with IT adoptions New Zealand and Canada in 1990 and 1991, respectively. Also Brito and Bystedt (2010), studying the effects of IT on emerging markets using dynamic panel data methods, find no evidence that IT improves the performance of inflation and output growth. Although in their work there seems to be some indication that IT reduces inflation, this reduction is not robust to alterations in the control group of non-IT countries. They even report lower output growth after IT adoption. Agénor and Pereira da Silva (2013) discuss a variety of factors relevant to the developing world within the IT framework. Also, Canuto and Cavallari (2013) address the implications of monetary policy's neglect of asset price booms and busts, as well as how to integrate macro prudential factors into central bank policy.

Mollick, Cabral and Carneiro $(2008,2011)$ blended the economic growth model with IT and examined the effects of IT on output per capita growth using the database of Lane and Milesi-Ferretti (2007) with samples of industrial and emerging economies facing increasing trade and financial integration for the period 1986- 2004. In those studies, the authors adopted a real output growth perspective and introduced controls for factors such as globalization (trade and capital flows) as well as IT. They found that the adoption of a fully-fledged IT regime results in higher output and income per capita. 
In a time series context for a country by country empirical analysis, Moura and Carvalho (2010) used forecasting techniques and found that Mexico and Brazil pursue a "tough" monetary policy, Chile and Peru pursue "mild" monetary policy against inflation, while Argentina, Colombia, and Republica Bolivariana de Venezuela do not change nominal interest rates in response to inflation, thus following "lax" policies. In their analysis, changes in the nominal exchange rate only appear to have an impact in Mexico during the period from January 1999 to January 2008. Civcir and Akcaglayan (2010) performed a VAR analysis for Turkey before and after the country adopted inflation targeting in early 2001. They found that nominal exchange rate deviations from its trend had a positive impact on interest rates after IT adoption, but not before. Another issue investigated in the literature is the extent to which "strict IT" adopters (implying a fully flexible exchange rate) perform better or worse than those that adopt a "flexible IT" regime (which results in foreign exchange interventions to moderate exchange rate volatility). Berganza and Broto (2012) examine 18 emerging markets that have adopted IT and a control group of 19 non-IT countries from 1995Q1 to 2010Q1 and find that foreign exchange (FX) interventions in some IT countries have been more effective to lower volatility than in non-IT countries. Cabral (2010) uses an asymmetric two-country model and shows that although dollarization is an effective device to achieve price stability and avoid credibility problems small open economies might be better off under a flexible regime than under dollarization following any symmetric or asymmetric shock. This suggests that the exchange rate regime is important and may incur a pass-through effect to interest rates that is not as straightforward as it may have been suggested.

Whether the central bank should target the exchange rate or not is also a matter of debate in the theoretical literature. In an overview of the early literature, Taylor (2001) concludes that monetary policy rules that, in addition to output and inflation, also react directly to the exchange rate do not 
work much better in stabilizing inflation and real output since exchange rate movements are already indirectly taken into consideration in an IT framework. Leitemo and Södeström (2005) use a New Keynesian open economy model and arrive at similar results, which suggest that including the exchange rate in the Taylor interest rate rule provides no gains even under exchange rate uncertainty.

Contrasting evidence is presented by Wollmershaüser (2006), who follows closely the idea of Leitemo and Söderström. He shows that under a significant degree of exchange rate uncertainty, open economy rules become superior to simple policy rules that merely target output and inflation. Similarly, Pavasuthipaisit (2010) uses an open economy Dynamic Stochastic General Equilibrium (DSGE) model to examine monetary policy under commitment and shows that, in the absence of complete information, the exchange rate might provide useful information for the policy making process and therefore it might be beneficial for the central bank to act upon the exchange rate. Also using a DSGE model, Garcia et al. (2011) assess whether including the exchange rate in the central bank policy rule helps economic performance across economies with strong and vulnerable financial markets. They observe that there are benefits associated with smoothing the exchange rate for both types of economies but, due to the pervasive effects of the demand on exchange rate movements, smoothing is more beneficial for financially vulnerable emerging markets than across financially strong industrial economies.

The literature above suggests that there is merit in considering the exchange rate as part of the central bank policy decisions. Indeed, the literature provides an extensive list of factors for the purpose of explaining exchange rates, including inter alia (relative) money supplies, output growth, price movements and net foreign asset positions. Rossi (2013) reviews the literature on exchange rate forecasting and documents the relevance of "Taylor-rule" or net foreign assets (related to financial globalization) in forecasting exercises for several advanced economies using a variety of methods. 
This paper uses the central bank reaction function as framework for the interest rate-exchange rate relationship in emerging market economies. The literature reviewed above suggests that the exchange rate has a role in determining the policy variable, although in varying degrees across emerging markets. ${ }^{1}$ The literature also indicates a wide range of topics underlying the interest rateexchange rate nexus within IT. Our empirical research approach is close to Aizenman, Hutchison, and Noy (2011) who estimate a Taylor rule reaction function for 16 emerging-market countries for the period 1989Q1 to 2006Q4 employing fixed-effects panel data methods. Our analysis differs from them in at least two important ways. First, we employ dynamic panel methods, which are better at controlling for potential endogeneity problems that emerge from having inflation and exchange rate variations on the right-hand side. With this, we allow for effects from interest rates (the policy variable) to currency, which is consistent with the UIP literature. It is also reasonable to assume that increases in domestic rates will affect the output and inflation gaps: a contractionary monetary policy that increases interest rates is expected to reduce any positive output and inflation gaps. Second, we expand the sample of countries and consider the effects of the recent financial crisis on the way that central banks respond to exchange rate developments but also to the rest of the variables in their reaction function. These considerations lead us to propose alternative empirical strategies to the fixedeffects modeling by Aizenman, Hutchison, and Noy (2011).

\section{Empirical approach}

\footnotetext{
${ }^{1}$ Exchange rates may, of course, lead to inflationary effects, which forms an empirical matter of its own. Nogueira and León-Ledesma (2009), for example, use monthly data from 1995M1 to 2007M12 for Brazil and estimate inflation as a function of its past, real output growth, changes in nominal exchange rates, and changes in the price of foreign imports. They find that, after the policy change and adoption of IT in 1999M1 long-run exchange rate pass-through declined dramatically. Under the peg, exchange rate changes are more fully transmitted to prices. Also, under a credible IT nominal shocks are expected to have only limited effects on inflation.
} 
Our sample comprises 24 emerging market economies: nine are inflation targeters and 15 are non-targeters. The period analyzed extends from the first quarter of 2000 to the second quarter of 2015, following periods of turmoil in the late 1990s for emerging markets, including the Asian crisis of 1997-98, the Russian debt crisis of 1998 and the Brazilian abandon of its pegged exchange rate regime in early 1999. The main source for our data is the IMF International Financial Statistics; only the interest rates were taken from individual country sources. Interest rates are the benchmark policy rates (or, alternatively, the money market, discount or short-term T-bill rates if the benchmark is not available), inflation is measured by consumer price index (CPI) changes in all countries, and real gross domestic product (RGDP) gap is RGDP growth compared to trend generated by HodrikPrescott (HP) filter. Exchange rates are the bilateral currency of each emerging market against the U.S. dollar (USD). We also collected real exchange rates for currencies of emerging markets against a basket of currencies but there were less data availability in this case to operate consistently across countries. For this reason, we will focus below on the estimates of each currency against the USD.

Table 1 lists the countries and their respective averages of inflation, interest rates, GDP growth and nominal exchange rates against the U.S. dollar. In terms of inflation, two digit rates are reported only across non-IT countries (Dominican Republic, Ecuador and Nigeria) and the highest average inflation among ITers is observed in Brazil with 6.62\%. Two digits average interest rates are observed in five non-IT countries (Argentina, Costa Rica, Dominican Republic, Nigeria and Pakistan) but only in one inflation targeter (Brazil). The four fastest growing economies in the sample are part of the group of non-targeters: China (9.87\%), Nigeria (8.05\%) and Panama (7.27\%). Across the inflation targeters the two with the highest average GDP growth rates are Peru (5.81\%) and the Philippines (5.1\%). As for exchange rate changes, three countries in the sample of non-targeters are dollarized economies: Panama (since 1904), Ecuador (2000) and El Salvador (2001). Because of this they 
observe no exchange rate changes. Across the inflation targeters the highest average exchange rate changes are reported in Brazil and, across non-targeters, in Argentina, which was subject to a currency crisis in the early part of the sample (2001 and 2002).

Some stylized facts can also be validated when we compare targeter and non-targeter group averages. For instance, inflation targeters show lower average inflation (3.97\%) relative to the noninflation targeters $(6.27 \%)$. Given this lower inflation, the group of targeters also present lower nominal interest rates $(6.41 \%)$ than their counterparts $(7.15 \%)$. Inflation targeters also experience lower economic growth (3.58\%) than non-targeters (5.15\%). Finally, ITers observe significant lower exchange rate variability $(0.28 \%)$ than non-inflation targeters $(0.73 \%)$. This last property makes our sample particularly different from earlier ones, such as Aizenman et al. (2011), who collect quarterly data from 1989 to 2006 for 16 countries (11 inflation targeters and 5 non-inflation targeters) and report average changes in real exchange rates of $2.50 \%$ for inflation targeters and $-0.49 \%$ for noninflation targeters, which yields a close to $3 \%$ real exchange rate depreciation for targeters compared to non-targeters. In contrast, in our sample from 2000 to 2015, countries that follow IT practices have their currencies fluctuating by much less when compared to non-IT adopters. ${ }^{2}$

\subsection{The model}

We employ a panel data approach that allows us to consider an aggregate specification for all countries in the sample. Following Aizenman, Hutchison, and Noy (2011), who run Taylor rule-type

\footnotetext{
${ }^{2}$ In Aizenman et al. (2011), real GDP growth was relatively close across samples: $1.11 \%$ versus $1 \%$. However, their figures were similar to ours on monetary policy: inflation targeters show lower average inflation $(5.40 \%)$ relative to the non-inflation targeters $(9.60 \%)$ and the group of targeters present lower nominal interest rates $(8.98 \%)$ than their counterparts (12.68\%). Therefore, in addition to slower economic growth for ITers in our sample, the rate of change of exchange rates is much lower for ITers on average: $0.28 \%$ versus $0.73 \%$.
} 
regressions in a panel data context for 16 emerging market countries, we estimate the corresponding dynamic specification for nominal interest rates as follows:

$$
\mathrm{i}_{\mathrm{it}}=\beta_{0}+\beta_{1} \mathrm{iit}_{\mathrm{it}-1}+\beta_{2}\left(\mathrm{y}_{\mathrm{it}}-\mathrm{yi}^{*}\right)+\beta_{3} \pi_{\mathrm{it}}+\beta_{4} \mathrm{e}_{\mathrm{it}}+\Sigma \beta_{\mathrm{j}} \mathrm{X}_{\mathrm{it}}+\varepsilon_{\mathrm{it}}
$$

where: $\mathrm{i}$ is the interest rate, $\left(\mathrm{y}_{\mathrm{it}}-\mathrm{y}_{\mathrm{i}}{ }^{*}\right)$ is the output gap, $\pi_{\mathrm{it}}$ is the inflation rate, and e is the bilateral nominal exchange rate currency against the USD and $\mathrm{X}_{\mathrm{it}}$ is a vector of additional control variables, including an IT dummy for countries that adopted the regime, a financial crisis dummy that takes the value of unity after the third quarter of 2007, and an interaction between these two and exchange rate variations. The subscripts index countries (i) and time (t). The coefficients interpretations are as follows: $0<\beta_{1}<1$ is the interest rate smoothing parameter, $\beta_{2}$ measures deviations of output from its potential (estimated by HP filter), $\beta_{3}$ measures effect of inflation on the interest rate, and $\beta_{4}$ is the coefficient of exchange rates (nominal or real) affecting the policy variable. Both $\beta_{2}$ and $\beta_{3}$ should be $>0$ under IT. Correspondingly, the exchange rate indicates the extent of currency movements against a major foreign currency (USD). If $\beta_{4} \neq 0$ in (1), this channel is operative. ${ }^{3}$ Aizenman, Hutchison, and Noy (2011) employ a fixed-effects least-squares procedure (LSDV) and find $\beta_{2}$ to be positive and statistically significant in the baseline model for countries that adopt IT (and, for non-IT countries, positive only when RER is included), $\beta_{3}$ is not statistically significant, and $\beta_{4}$ is positive and statistically significant in the baseline model: 0.07 for IT countries and 0.13 for non-IT countries. The latter implies that, in response to a depreciation of the real effective exchange rate, central banks in their sample of 16 countries move domestic interest rates upwards.

\footnotetext{
${ }^{3}$ Canuto and Cavallari (2013) discuss whether central banks should incorporate indicators of financial stability into the reaction function. While one may associate asset prices with home and equity markets, private sector credit could indicate as well the extent of bank lending to the private sector. We might as well consider alternative factors to the exchange rate such as private credit, money growth and other financial conditions.
} 
We start by estimating the Taylor-rule equations in (1) by fixed-effects (FE) ordinary least squares, which produces consistent estimators for large samples. Thereafter, we employ SGMM estimations. Under this technique, lags and lagged differences of their own are used to instrument endogenous variables. This provides more robust estimations when the autoregressive process becomes persistent. Moreover, there are reasons established from economic theory that justify the reverse causation from interest rates in the central bank's rule to the real economy. Interest rate changes have well-known effects on aggregate demand components: increases in interest rates lower consumption expenditures and desired investment on capital purchases, thus contracting output. A contractionary monetary policy also reduces inflation, although with a lag as well document in VAR models of the "price puzzle". In addition, increases in home interest rates - for given interest rates abroad (U.S. interest rates in this case) - imply a higher rate of depreciation of the exchange rate by uncovered interest parity (UIP) condition. All these channels suggest that interest rate changes have an effect on the economy (rate of growth of prices of goods and services and economic growth rate), as well as on the financial price of the open economy (the exchange rate).

In order to deal with potential over identification problems that arise from using SGMM when the time dimension of the panel is large relative to the number of countries, instruments will be restricted by using the collapse procedure proposed by Roodman (2009). We limit the number of lags in time for the collapse procedure such that the number of instruments becomes smaller than the number of cross-section units.

A recent application of the technique to the topic has been proposed by Poon and Lee (2014) for a sample of 10 ASEAN economies (3 of which are IT-targeters: Indonesia, the Philippines and Thailand) from 1990 to 2010 (annual data). They find first, under fixed-effects methods, that "the coefficients of real exchange rate when setting interest rates are highly significant in the non-IT 
countries as compared with the IT countries despite their lower magnitude. One possible explanation is that IT countries attempt to "lean against the wind", in which the IT group attempts to minimize the exchange rate fluctuation by using the interest rates (Poon and Lee 2014). When they switch to dynamic panels, however, the impact of the real exchange rate becomes mixed: varying from positive and statistically significant at $10 \%$ in dynamic generalized method of moments (DGMM) to negative and not statistically significant in SGMM. We believe that further work - using different samples of countries, frequency (quarterly observations), time period, and methodological assumptions on the policy rule (1) - is needed to verify the robustness of the exchange rate factor in the interest rate policy rule under dynamic panels.

\section{Econometric results}

\subsection{Fixed effects estimations}

Table 2 presents the estimations of equation (1) employing fixed-effects least-squares estimation techniques. Since a bias exist in fixed effects estimations when a lagged dependent variable is included in the right hand side, we also present a static version of equation (1) in columns (1) to (4), along with the dynamic version in (5) to (8). For the static model, column (1) estimates a simpler version of the Taylor rule that controls only for inflation and the output gap. Column (2) includes the exchange rate as an additional regressor, while columns (3) and (4) control also for the effect of the financial crisis and whether the country has adopted IT or not. The models without lagged interest rates in the first 4 columns suggest between $27 \%$ and $35 \%$ (using $\mathrm{R}^{2}$ between; much larger for $\mathrm{R}^{2}$ overall) of the variations in interest rates are explained by the regressors listed, with the traditional Taylor rule components in the lower bound of $27 \%$. Adding the persistence of lagged interest rates 
brings the figures to the $73 \%-74 \%$ range, which is close to the values reported by Aizenman et al. (2011) for their earlier sample with fixed-effects methods.

Comparing the static and dynamic models results we observe first a contrasting impact of inflation on the interest rates. When the lagged dependent variable is excluded from the model, inflation presents a positive expected coefficient, which is statistically significant at the $1 \%$ level in every case. Inflation is not, however, significant in a dynamic set up. For our main variable of interest, the changes in the exchange rate, we observe positive and statistically significant coefficients under both specifications. However, the coefficients are larger and pose a higher statistical significance under the static model (5\% level) than under the dynamic specification $(10 \%)$. The positive responses are consistent with central banks moving up interest rates when the home currency depreciates. Looking at the effects of the crisis on interest rates, we only observe meaningful coefficients (and negative, as expected) when we estimate the static specification. In the case of the output gap change, this variable was never statistically significant (yet changing signs across models), and this could imply that the central banks may not be as much concerned about GDP growth than about inflation as far as monetary policy response is needed.

Overall, the static model appears more reasonable than the dynamic one in Table 2 due to the estimated responses. In the dynamic model the $\mathrm{R}^{2}$ improves (due to high persistence of the lag of monetary policy) but all else (than exchange rate changes) is not statistically significant in columns (5)-(8). A problem we still observe in these dynamic specifications of the fixed-effect models is that of endogeneity between, for instance, the interest rate and inflation or between the interest rate and the exchange rate. In what follows, we address this potential problem by employing SGMM estimations, which instrument endogenous variables with suitable lags of their own and lagged differences. 


\subsection{System GMM estimations}

In Table 3 we replicate the estimations in Table 2 using SGMM estimates. Taking advantage of the method, we consider in the estimations of Table 3 inflation and exchange rate variations as endogenous, following initially the results from the FE model reported in Table 2. In Tables 4 and 5 we will next consider output gap also as endogenous to interest rates in the more general SGMM of the reaction function. Since the financial crisis dummy was not statistically significant before or in these estimations, we exclude this variable from the model and instead add an interaction between the IT dummy and the exchange rate change. This allows us to distinguish between how much weight inflation targeting economies and non-targeters assign to exchange rate variations.

In general, the results are qualitatively not very different from those observed in Table 2 . In the static model, inflation is positive and statistically significant at the $1 \%$ level in every specification. The output gap is always positive but only statistically significant in two of the static model specifications at the $10 \%$ level. The exchange rate is only relevant in column (4) along with the interaction between IT and the dummy variable. The significance of both coefficients suggests that the exchange rate is relevant for the reaction function of the central bank but less so for the inflation targeters than the non-targeters. This, despite the fact that the IT dummy per se was not statistically significant in columns (3) or (4).

Moving to the dynamic specification, in addition to the statistical significance of the lagged interest rate with high persistence in column (5) at 0.844 or milder persistence in columns (6) to (8), we observe again positive and a very strong statistically significant effect of the exchange rate on the interest rate. This time, however, larger in size and more statistically relevant than under fixed effects estimations. In response to weaker currencies, central banks respond by raising the benchmark interest rates. Just as in the static model specification, the IT dummy is not statistically significant but its 
interaction with the exchange rate variations is negative and statistically significant. Once again, this implies that while both inflation targeters and non-targeters are concerned about the exchange rate, the former are less reactive to exchange rate variations than the latter. Diagnostic tests for serial correlation (first and second order, $\mathrm{AB}(1)$ and $\mathrm{AB}(2)$, respectively ${ }^{4}$ ) and instrument validity (Hansen test) are satisfactory in the static and dynamic specifications, for the latter test the number of instruments lower (20 to 22) than the number of cross-section units (24).

\subsection{Robustness checks}

In order to investigate further the different effect of the exchange rate on the reaction function of central banks, we employ two approaches. First, we split the sample and estimate separately the Taylor rule of inflation targeter and non-targeter economies. This allows us to revisit whether inflation targeters and non-targeters act differently when facing exchange rate developments. Secondly, we partition the sample into two periods: before and after the financial crisis. This explores the possibility that the recent financial crisis might have brought a structural change in the way that central banks react and manage their policy rate. In what follows, we also bring back the financial crisis dummy to see if the two groups are affected differently by this shock. Finally, we also control for the potential endogeneity of the output gap and instrument it accordingly.

In Table 4 we present the estimates of the full sample and the two subsamples of inflation targeters and non-targeters. The results for the full sample are very much in line with the previous results where only the lagged interest rate and the nominal exchange rate variations were statistically significant. Interestingly, when we split the sample the nominal exchange rate remains statistically significant only across those economies that do not target inflation. Meanwhile, the inflation rate now

\footnotetext{
${ }^{4}$ For the static model, the absence of first order serial correlation tests is relevant, while for the dynamic model second order serial correlation test is most important.
} 
shows a positive and statistically significant coefficient across the group of inflation targeting economies. These results suggest that central banks in inflation targeting and non-targeting economies do not react as much to economic growth and put different weights on their reaction functions when considering inflation and the exchange rate variations. ${ }^{5}$

In Table 5 we estimate the model partitioning the sample in two periods, the period before the financial crisis, third quarter of 2007, and the period after. We first notice the much higher persistence of the interest rate in the post crisis period: lagged coefficient of 0.48 versus 0.86 during crisis. This suggests a considerable amount of inertia in monetary policy more recently, with inflation as the only other factor of relevance. In fact, when looking at the inflation rate coefficients we see that those are statistically significant in all columns after the crisis but not before it. Comparing the most complete specification in columns (3) and (6), inflation is in fact not statistically significant before the crisis but significant at the $1 \%$ level afterwards. Paying closer attention to the coefficient of exchange rate variations, this is only statistically relevant in the pre-crisis period. In column (3) while the IT dummy is not statistically relevant, its interaction with the exchange rate is negative and significant. As before, the partial effect of the exchange rate is smaller for inflation targeting countries than for non-targeters. On the other hand, the exchange rate variations are not statistically relevant following the financial crisis, neither for non-targeters nor for targeters.

It is useful to place in context the estimates of the previous tables across methods that either take the economy as exogenous to monetary policy or allow the economy to respond to monetary policy. Fixed-effect models in Table 2 indicate an exchange rate coefficient of about 0.192 or 0.195 in columns (2) to (4). In Table 3, with the lagged dependent variable, estimates of the exchange rate

\footnotetext{
${ }^{5}$ The caveat for the subsample of ITers with only 9 countries in columns (4) to (6) of Table 4 is that some serial correlation shows up at around the 5\% significance level.
} 
coefficient vary between 0.293 and 0.400 in columns (6) to (8), which reinforces the role of interest rate changes on the economy under SGMM. Moreover, if we confine ourselves to non-ITers countries only in Table 4 estimates of the exchange rate coefficient vary between 0.563 and 0.587 in columns (9) and (8), suggesting an even larger response to currency movements in countries that do not adopt IT. Central banks in these countries put, presumably, less weight on rules in the conduct of monetary policy and therefore may be more inclined to move up the benchmark rate when currency changes. They may do so for anchoring inflation expectations or for making interest rates more attractive to attract capital inflows: the interest rate defense of the 1990s examined by Flood and Rose (2002). Similarly, for the partition in Table 5 for the years before the crisis estimates of the exchange rate coefficient vary between 0.560 and 0.587 in columns (1) to (3) of Table 5. These figures are in about the same range as those in Table 4 for non-ITers just discussed. One interpretation might be that during 2000-2007 there was, on average, more deviation from rules than since the crisis onwards led emerging markets to follow more discipline and thus respond primarily to macroeconomic developments, such as inflation.

Overall, these robustness checks suggest that inflation targeting and non-targeting countries react differently to exchange rate developments with the former group having a more passive attitude towards exchange rate variations than the latter. This matches insights by minimizing a loss function in Aizenman et al. (2011) and also discussed by Edwards (2006), who stated that “... if the authorities have modeled the economy correctly (and, in doing so, have incorporated the effects of e on $\pi$ and y), there is no need to include an exchange rate term in (the IT) equation." We also observe a structural change in the way that central banks react to the exchange rate and other variables in their reaction function, with a more reactive attitude towards inflation and less role for exchange rate changes in 
influencing monetary policy after the financial crisis when monetary policy in emerging markets responds only to its own past and inflation rate movements.

\section{Conclusions and policy implications}

In this paper we employ an augmented Taylor rule to model the reaction function of the central bank with the objective of modeling the interest rate-exchange rate relationship within the context of emerging markets. Building on previous literature assessing this relationship, we reexamine the relevance of the exchange rate across a sample of 24 EMEs: 9 inflation targeters and 15 non-targeters. Relying first on a fixed effects model, we observe that the exchange rate plays an important role in the central bank policy rule. When we consider the endogeneity of the inflation rate and the exchange rate in our model, our results confirm the persistence of the exchange rate on the EMEs reaction function, yet with far less importance for the inflation targeting economies when compared with nontargeters.

We test the robustness of our results by splitting the sample of countries across groups and time. First, we partition the sample separating inflation targeters from non-targeters. The results of this experiment show that the exchange rate has a positive and statistically significant effect on the reaction function of the non-inflation targeters group only. Second, when we split the sample before and after the recent financial crisis, the effect of the exchange rate on the central bank reaction function vanishes. This suggests that there is likely to be a structural change in the way central banks react to the exchange rate and other variables in their reaction function, with a more reactive attitude towards inflation and a lesser role for exchange rate changes in influencing monetary policy.

As floating exchange rate mechanisms have become increasingly more popular in emerging markets, reconsidering the nexus between interest rates and exchange rate movements becomes an 
important endeavor as it sheds new light on the empirical question as to whether exchange rates are determined by factors other than interest rate differentials in emerging market economies. Our results show that central banks of EMEs that follow IT rules react only to inflation movements, suggesting a limited role for other factors in the policy rule. For non-IT countries, an adjustment term related to exchange rate movements appears as statistically significant, which might be suggestive that currency volatility could be linked to the policy rule for this set of countries that do not target inflation.

Our results suggest that despite the low GDP growth environment observed in the period post financial crisis, central banks in EMEs do not react to variations in their output gap. While further research into this matter is warranted, this finding suggests that central banks in EMEs have been more cautious in their monetary policy stances and are nowadays more concerned about price stability than about short-term economic growth. In line with this, our results seem to corroborate the argument that IT can be classified as a macroeconomic policy tool that lends transparency and credibility to monetary policy while supporting the monetary authorities to adopt a monetary policy framework that creates incentives for long-term price stability. In simple terms, following an approach akin to the IT mechanism seems to be useful in helping central banks anchor expectations about price movements, making macroeconomic management easier (see World Bank, 2014).

Finally, it is worth mentioning that although there seems to be an emerging consensus in the literature that central banks have tended to pursue price stability as one of their primary objectives, the adoption of an IT regime may not be the most appropriate solution for all countries. As argued by Eichengreen et al. (1999) and Mishkin (2004), for example, to be successful with the adoption of an IT policy, countries need to meet certain criteria that rest on an improved understanding of the monetary transmission channels and on the capacity of the central bank to actually pursue price stability with technical competence and without political interference. For countries that do not meet 
these pre-conditions, an interim option is to resort to a forward-looking approach to monetary policy, with interest-rate focused operating procedures to achieve inflation objectives until the pre-conditions to adopt a fully-fledged IT regime can be put in place (Laurens et al., 2015). 


\section{References}

Agénor, Pierre-Richard, and Luiz A. Pereira da Silva (2013). Rethinking Inflation Targeting: A Perspective from the Developing World. University of Manchester, Centre for Growth and Business Cycle Research, Economic Studies, Discussion Paper Series, Number 185, July 2013.

Aizenman, Joshua, Michael Hutchison, and Ilan Noy (2011). Inflation Targeting and Real Exchange Rates in Emerging Markets. World Development 39 (5): 712-724.

Ball, Laurence, and Niamh Sheridan (2005). Does Inflation Targeting Matter? In: The Inflation Targeting Debate. NBER Studies in Business Cycles 32. Chicago: The University of Chicago Press.

Batini, Nicoletta and Douglas Laxton (2007). Under what conditions can inflation targeting be adopted? The experience of inflation targeting in emerging markets, in: Monetary Policy under Inflation Targeting, edited by Frederic Mishkin and Klaus Schmidt-Hebbel, Santiago, Chile. Central Bank of Chile.

Bernanke, B. (2003), A Perspective on Inflation Targeting, The Federal Reserve Board, Washington, DC.

Berganza, Juan Carlos, and Carmen Broto (2012). Flexible Inflation Targets, Forex Interventions and Exchange Rate Volatility in Emerging Countries. Journal of International Money and Finance 31: 428-444.

Brito, R. D., \& Bystedt, B. (2010). Inflation targeting in emerging economies: Panel evidence. Journal of Development Economics 91 (2): 198-210.

Cabral, René (2010). Why Dollarization Didn't Succeed: Comparing Credibility and the Impact of Real Shocks on Small Open Economies. North American Journal of Economics and Finance 21 (3): 297-313.

Canuto, Otaviano and Matheus Cavallari (2013). Monetary Policy and Macroprudential Regulation: Whither Emerging Markets, The World Bank: Policy Research Working Paper 6310.

Civcir, Irfan and Anil Akcaglayan (2010). Inflation Targeting and the Exchange Rate: Does it Matter in Turkey? Journal of Policy Modeling 32: 339-354.

Edwards, S. (2006). The Relationship between Exchange Rates and Inflation Targeting Revisited. NBER Working Paper No. 12163, April.

Eichengreen, B., P. Masson, M. Savastano, and S. Sharma (1999). Transition Strategies and Nominal Anchors on the Road to Greater Exchange-Rate Flexibility. In Essays in International Economics, N. 213. International Finance Section, Department of Economics, Princeton, N.J.: Princeton University.

Flood, Robert, and Andrew Rose (2002). Uncovered Interest Parity in Crisis. IMF Staff Papers 49 (2): 252-266. 
Fraga, Arminio, Ilan Goldfajn, and André Minella (2003). Inflation Targeting in Emerging Market Economies, NBER Working Paper No. 10019.

Frankel, Jeffrey, and Jumana Poonawala (2010). The Forward Market in Emerging Currencies: Less Biased than in Major Currencies. Journal of International Money and Finance 29: 585-598.

Garcia, C. J., Restrepo, J. E., \& Roger, S. (2011). How much should inflation targeters care about the exchange rate? Journal of International Money and Finance 30 (7): 1590-1617.

International Monetary Fund, 2005. Global Financial Stability Report. Washington, D.C.: International Monetary Fund.

Lane, Philip and Gian Maria Milesi-Ferretti (2007). The External Wealth of Nations Mark II: Revised and Extended Estimates of Foreign Assets and Liabilities, Journal of International Economics 73: 223-250.

Laurens, B., K. Eckhold, D. King, N. Maehle, A. Naseer, and A. Durré (2015). The Journey to Inflation Targeting: Easier Said than Done. The Case for Transitional Arrangements along the Road. IMF Working Paper WP/15/136. Washington, D.C.: International Monetary Fund.

Leitemo, K., \& Söderström, U. (2005). Simple monetary policy rules and exchange rate uncertainty. Journal of International Money and Finance, 24(3), 481-507.

Loayza, Norman and Raimundo Soto (2002). Inflation Targeting: Design, Performance, Challenges, Central Bank of Chile, Santiago, Chile.

Mishkin, Frederic, 2004, Can Inflation Targeting Work in Emerging Market Countries? NBER Working Paper 10646.

Mishkin, Frederic and Klaus Schmidt-Hebbel (2007a). Does Inflation Targeting Make a Difference?, NBER Working Paper No. 12876.

Mishkin, Frederic and Klaus Schmidt-Hebbel (2007b). Monetary Policy under Inflation Targeting, Central Bank of Chile, Santiago, Chile.

Mollick, André V., Cabral, René, and Carneiro, Francisco G. (2008). Does Inflation Targeting Matter for Output Growth? Evidence from Industrial and Emerging Economies. World Bank Working Policy Paper (WP \# 4791), December of 2008.

Mollick, André V., Cabral, René, and Carneiro, Francisco G. (2011). Does Inflation Targeting Matter for Output Growth? Evidence from Industrial and Emerging Economies. Journal of Policy Modeling 33: 537-551.

Moura, Marcelo, and Alexandre de Carvalho (2010). What can Taylor Rules say about Monetary Policy in Latin America? Journal of Macroeconomics 32: 392-404.

Nogueira, Reginaldo, and Miguel León-Ledesma (2009). Fear of Floating in Brazil: Did Inflation Targeting Matter? North American Journal of Economics and Finance 20: 255-266. 
Oudiz, G. and J. Sachs (1984) Macroeconomic policy coordination among the industrial economies, Brookings Papers on Economic Activity 1, 1-64.

Pavasuthipaisit, R. (2010). Should inflation-targeting central banks respond to exchange rate movements? Journal of International Money and Finance, 29(3), 460-485.

Poon, Wai Ching, and Yong Shen Lee (2014). Inflation Targeting in ASEAN-10. South African Journal of Economics 82 (1): 141-157.

Roodman, D. (2009). A Note on the Theme of Too Many Instruments. Oxford Bulletin of Economics and Statistics 71 (1): 135-158.

Roger, S. (2009). Inflation targeting at 20: Achievements and challenges. IMF working paper no. $09 / 236$.

Rossi, Barbara (2013). Exchange Rate Predictability. Journal of Economic Literature 51 (4): 10631119.

Taylor, J.B. (1985) International coordination in the design of macroeconomic policy rules, European Economic Review 28, 53-81.

Taylor, J. B. (2001). The role of the exchange rate in monetary policy rules. American Economic Review, 91:263-67(2), 263-267.

Taylor, J.B. (2013) International monetary coordination and the great deviation, Journal of Policy Modeling 35, 463-472.

Wollmershäuser, T. (2006). Should central banks react to exchange rate movements? An analysis of the robustness of simple policy rules under exchange rate uncertainty. Journal of Macroeconomics, 28(3), 493-519.

World Bank (2014). Risk and Opportunity - Managing Risk for Development. World Development Report 2014. The World Bank. Washington, DC. 
Table 1. Descriptive statistics

\begin{tabular}{|c|c|c|c|c|}
\hline Countries & Inflation & $\begin{array}{l}\text { Interest } \\
\text { rate }\end{array}$ & $\begin{array}{l}\text { GDP } \\
\text { growth }\end{array}$ & $\begin{array}{c}\text { Nominal } \\
\text { exchange } \\
\text { rate } \\
\text { change }\end{array}$ \\
\hline Brazil & 6.62 & 14.04 & 3.17 & 1.23 \\
\hline Colombia & 5.07 & 6.52 & 4.35 & 0.57 \\
\hline Czech Republic & 2.37 & 2.09 & 2.64 & -0.47 \\
\hline Hungary & 4.98 & 7.56 & 1.90 & 0.30 \\
\hline Israel & 1.92 & 4.07 & 3.43 & -0.01 \\
\hline Mexico & 4.72 & 7.42 & 2.20 & 0.91 \\
\hline Peru & 2.72 & 3.76 & 5.81 & -0.19 \\
\hline Philippines & 4.28 & 6.06 & 5.10 & 0.20 \\
\hline Poland & 3.01 & 6.13 & 3.65 & 0.03 \\
\hline ITers average & 3.97 & 6.41 & 3.58 & 0.28 \\
\hline Argentina & 9.43 & 12.14 & 4.43 & 4.41 \\
\hline Bangladesh & 6.51 & 5.56 & 5.94 & 0.71 \\
\hline Bulgaria & 4.98 & 2.21 & 3.44 & -0.08 \\
\hline China & 2.27 & 5.87 & 9.87 & -0.49 \\
\hline Costa Rica & 8.72 & 11.40 & 4.34 & 0.97 \\
\hline Dominican Republic & 10.21 & 12.84 & 5.16 & 1.91 \\
\hline Ecuador & 13.01 & 8.96 & 4.50 & 0.00 \\
\hline El Salvador & 2.90 & 3.62 & 1.92 & 0.00 \\
\hline Indonesia & 7.47 & 9.67 & 5.42 & 1.09 \\
\hline Malaysia & 2.22 & 2.89 & 4.71 & -0.03 \\
\hline Morocco & 1.64 & 3.43 & 4.55 & 0.00 \\
\hline Nigeria & 11.66 & 12.67 & 8.05 & 1.04 \\
\hline Pakistan & 8.50 & 10.45 & 4.40 & 1.15 \\
\hline Panama & 2.96 & 2.06 & 7.27 & 0.00 \\
\hline Tunisia & 3.81 & 4.20 & 4.80 & 0.74 \\
\hline Non-ITers average & 6.27 & 7.15 & 5.15 & 0.73 \\
\hline Full sample average & 5.50 & 6.90 & 4.63 & 0.58 \\
\hline
\end{tabular}


Table 2. Fixed effects model (OLS)

\begin{tabular}{|c|c|c|c|c|c|c|c|c|}
\hline \multirow[t]{2}{*}{ Variables } & \multicolumn{4}{|c|}{ Static Model } & \multicolumn{4}{|c|}{ Dynamic Model } \\
\hline & (1) & (2) & (3) & (4) & $(5)$ & (6) & (7) & (8) \\
\hline Lagged interest rate & & & & & $\begin{array}{c}0.804 * * * \\
(0.074)\end{array}$ & $\begin{array}{c}0.773 * * * \\
(0.082)\end{array}$ & $\begin{array}{c}0.770 * * * \\
(0.082)\end{array}$ & $\begin{array}{c}0.770 * * * \\
(0.082)\end{array}$ \\
\hline Inflation & $\begin{array}{c}0.493 * * * \\
(0.059)\end{array}$ & $\begin{array}{c}0.476^{* * *} \\
(0.056)\end{array}$ & $\begin{array}{c}0.491 * * * \\
(0.053)\end{array}$ & $\begin{array}{c}0.491 * * * \\
(0.053)\end{array}$ & $\begin{array}{c}0.064 \\
(0.070)\end{array}$ & $\begin{array}{c}0.072 \\
(0.063)\end{array}$ & $\begin{array}{c}0.077 \\
(0.064)\end{array}$ & $\begin{array}{c}0.077 \\
(0.064)\end{array}$ \\
\hline Output gap change & $\begin{array}{c}0.003 \\
(0.003)\end{array}$ & $\begin{array}{c}0.003 \\
(0.003)\end{array}$ & $\begin{array}{c}0.003 \\
(0.003)\end{array}$ & $\begin{array}{c}0.003 \\
(0.003)\end{array}$ & $\begin{array}{l}-0.002 \\
(0.001)\end{array}$ & $\begin{array}{l}-0.001 \\
(0.001)\end{array}$ & $\begin{array}{l}-0.001 \\
(0.001)\end{array}$ & $\begin{array}{l}-0.001 \\
(0.001)\end{array}$ \\
\hline Exchange rate change & & $\begin{array}{c}0.192 * * \\
(0.093)\end{array}$ & $\begin{array}{c}0.195 * * \\
(0.092)\end{array}$ & $\begin{array}{c}0.195 * * \\
(0.092)\end{array}$ & & $\begin{array}{l}0.097 * \\
(0.050)\end{array}$ & $\begin{array}{l}0.098^{*} \\
(0.050)\end{array}$ & $\begin{array}{l}0.098^{*} \\
(0.050)\end{array}$ \\
\hline Crisis dummy & & & $\begin{array}{c}-1.279 * * * \\
(0.349)\end{array}$ & $\begin{array}{c}-1.279 * * * \\
(0.349)\end{array}$ & & & $\begin{array}{l}-0.276 \\
(0.180)\end{array}$ & $\begin{array}{l}-0.276 \\
(0.180)\end{array}$ \\
\hline IT dummy & & & & $\begin{array}{l}-3.665^{*} \\
(2.210)\end{array}$ & & & & $\begin{array}{l}-0.872 \\
(1.396)\end{array}$ \\
\hline Constant & $\begin{array}{c}6.977 * * \\
(2.814)\end{array}$ & $\begin{array}{c}6.338 * * * \\
(2.272)\end{array}$ & $\begin{array}{c}6.348 * * * \\
(2.272)\end{array}$ & $\begin{array}{c}6.348 * * * \\
(2.272)\end{array}$ & $\begin{array}{l}1.752 * \\
(1.013)\end{array}$ & $\begin{array}{l}1.629^{*} \\
(0.979)\end{array}$ & $\begin{array}{l}1.653^{*} \\
(0.979)\end{array}$ & $\begin{array}{l}1.653^{*} \\
(0.979)\end{array}$ \\
\hline Observations & 1261 & 1261 & 1261 & 1261 & 1257 & 1257 & 1257 & 1257 \\
\hline $\mathrm{R} 2$ overall & 0.611 & 0.647 & 0.653 & 0.653 & 0.854 & 0.863 & 0.863 & 0.863 \\
\hline R2 between & 0.268 & 0.335 & 0.347 & 0.347 & 0.726 & 0.742 & 0.743 & 0.743 \\
\hline
\end{tabular}

Notes: Newey-West robust standard errors to heteroscedasticity and serial correlation are reported in parenthesis. The symbols *, **, and *** refer to levels of significance of $10 \%, 5 \%$, and $1 \%$, respectively 
Table 3. SGMM Results.

\begin{tabular}{|c|c|c|c|c|c|c|c|c|}
\hline \multirow{2}{*}{ Variables } & \multicolumn{4}{|c|}{ Static Model } & \multicolumn{4}{|c|}{ Dynamic Model } \\
\hline & (1) & (2) & (3) & (4) & $(5)$ & (6) & (7) & (8) \\
\hline Lagged interest rate & & & & & $\begin{array}{c}0.844 * * * \\
(0.059)\end{array}$ & $\begin{array}{c}0.687 * * * \\
(0.117)\end{array}$ & $\begin{array}{c}0.687 * * * \\
(0.117)\end{array}$ & $\begin{array}{c}0.629 * * * \\
(0.109)\end{array}$ \\
\hline Inflation & $\begin{array}{c}0.531 * * * \\
(0.040)\end{array}$ & $\begin{array}{c}0.483 * * * \\
(0.039)\end{array}$ & $\begin{array}{c}0.483 * * * \\
(0.040)\end{array}$ & $\begin{array}{c}0.461 * * * \\
(0.048)\end{array}$ & $\begin{array}{c}0.027 \\
(0.121)\end{array}$ & $\begin{array}{c}0.091 \\
(0.068)\end{array}$ & $\begin{array}{c}0.090 \\
(0.069)\end{array}$ & $\begin{array}{l}0.107^{*} \\
(0.061)\end{array}$ \\
\hline Output gap & $\begin{array}{l}0.003^{*} \\
(0.001)\end{array}$ & $\begin{array}{c}0.002 \\
(0.002)\end{array}$ & $\begin{array}{c}0.002 \\
(0.002)\end{array}$ & $\begin{array}{l}0.002^{*} \\
(0.001)\end{array}$ & $\begin{array}{l}-0.002 \\
(0.001)\end{array}$ & $\begin{array}{c}-0.001 \\
(0.001)\end{array}$ & $\begin{array}{l}-0.001 \\
(0.001)\end{array}$ & $\begin{array}{c}-0.001 \\
(0.001)\end{array}$ \\
\hline Exchange rate change & & $\begin{array}{c}0.344 \\
(0.232)\end{array}$ & $\begin{array}{c}0.348 \\
(0.229)\end{array}$ & $\begin{array}{c}0.617 * * * \\
(0.237)\end{array}$ & & $\begin{array}{c}0.293 * * \\
(0.138)\end{array}$ & $\begin{array}{c}0.293 * * \\
(0.138)\end{array}$ & $\begin{array}{c}0.400^{* * *} \\
(0.063)\end{array}$ \\
\hline IT dummy (dIT) & & & $\begin{array}{c}0.399 \\
(1.051)\end{array}$ & $\begin{array}{c}0.596 \\
(1.112)\end{array}$ & & & $\begin{array}{c}0.037 \\
(0.332)\end{array}$ & $\begin{array}{c}0.153 \\
(0.430)\end{array}$ \\
\hline Exchange rate change $*$ dIT & & & & $\begin{array}{c}-0.588 * * \\
(0.234)\end{array}$ & & & & $\begin{array}{c}-0.372 * * * \\
(0.048)\end{array}$ \\
\hline Constant & $\begin{array}{c}4.210^{* * *} \\
(0.514)\end{array}$ & $\begin{array}{c}4.298 * * * \\
(0.511)\end{array}$ & $\begin{array}{c}4.135^{* * *} \\
(0.655)\end{array}$ & $\begin{array}{c}4.089 * * * \\
(0.674)\end{array}$ & $\begin{array}{c}0.865^{* *} \\
(0.344)\end{array}$ & $\begin{array}{c}1.513^{*} \\
(0.826)\end{array}$ & $\begin{array}{l}1.498^{*} \\
(0.866)\end{array}$ & $\begin{array}{l}1.749 * * \\
(0.815)\end{array}$ \\
\hline Observations & 1261 & 1261 & 1261 & 1261 & 1257 & 1257 & 1257 & 1257 \\
\hline Countries & 24 & 24 & 24 & 24 & 24 & 24 & 24 & 24 \\
\hline No. Instruments & 22 & 22 & 21 & 22 & 22 & 20 & 21 & 22 \\
\hline $\mathrm{AB}(1)$ & 1.146 & -0.939 & -0.946 & -1.080 & -1.105 & -1.337 & -1.337 & -1.348 \\
\hline $\mathrm{p}$-value & {$[0.252]$} & {$[0.348]$} & {$[0.344]$} & {$[0.280]$} & {$[0.269]$} & {$[0.181]$} & [0.181] & {$[0.178]$} \\
\hline $\begin{array}{l}\mathrm{AB}(2) \\
\quad \text {-value }\end{array}$ & $\begin{array}{l}-1.280 \\
{[0.201]}\end{array}$ & $\begin{array}{c}-0.876 \\
{[0.381]}\end{array}$ & $\begin{array}{c}-0.883 \\
{[0.377]}\end{array}$ & $\begin{array}{c}-0.758 \\
{[0.448]}\end{array}$ & $\begin{array}{l}-1.500 \\
{[0.134]}\end{array}$ & $\begin{array}{l}-1.005 \\
{[0.315]}\end{array}$ & $\begin{array}{l}-1.004 \\
{[0.315]}\end{array}$ & $\begin{array}{c}-0.915 \\
{[0.360]}\end{array}$ \\
\hline $\begin{array}{l}\text { Hansen } \\
\qquad \text {-value }\end{array}$ & $\begin{array}{l}23.369 \\
{[0.221]}\end{array}$ & $\begin{array}{l}22.354 \\
{[0.217]}\end{array}$ & $\begin{array}{l}20.390 \\
{[0.203]}\end{array}$ & $\begin{array}{l}20.680 \\
{[0.191]}\end{array}$ & $\begin{array}{c}19.638 \\
{[0.354]}\end{array}$ & $\begin{array}{l}17.582 \\
{[0.285]}\end{array}$ & $\begin{array}{c}17.651 \\
{[0.281]}\end{array}$ & $\begin{array}{c}18.876 \\
{[0.219]}\end{array}$ \\
\hline
\end{tabular}

Notes: Heteroscedasticity robust standard errors are shown in parenthesis. The Hansen test reports that under the null the over-identified restrictions are valid. $\mathrm{AB}(1)$ and $\mathrm{AB}(2)$ corresponds to Arellano-Bond test for serial correlation of first and second order, both under the null of no autocorrelation. The p-values for the Hansen test and the Arellano-Bond test of second order autocorrelation $(\mathrm{AB}(2))$ are shown in brackets. The symbols *, **, and $* * *$ refer to levels of significance of $10 \%, 5 \%$, and $1 \%$, respectively. 
Table 4. SGMM Results. Sample partition: ITers and Non-ITers.

\begin{tabular}{|c|c|c|c|c|c|c|c|c|c|}
\hline \multirow{2}{*}{ Variables } & \multicolumn{3}{|c|}{ Full Sample } & \multicolumn{3}{|c|}{ ITers } & \multicolumn{3}{|c|}{ NITers } \\
\hline & $(1)$ & $(2)$ & (3) & (4) & $(5)$ & $(6)$ & $(7)$ & $(8)$ & $(9)$ \\
\hline Lagged interest rate & $\begin{array}{c}0.890^{* * *} \\
(0.064)\end{array}$ & $\begin{array}{c}0.717 * * * \\
(0.120)\end{array}$ & $\begin{array}{c}0.712 * * * \\
(0.119)\end{array}$ & $\begin{array}{c}0.753 * * * \\
(0.057)\end{array}$ & $\begin{array}{c}0.759^{* * *} \\
(0.055)\end{array}$ & $\begin{array}{c}0.728 * * * \\
(0.067)\end{array}$ & $\begin{array}{c}0.851^{* * * *} \\
(0.048)\end{array}$ & $\begin{array}{c}0.363 * * \\
(0.175)\end{array}$ & $\begin{array}{l}0.357^{*} \\
(0.195)\end{array}$ \\
\hline Inflation & $\begin{array}{l}-0.016 \\
(0.136)\end{array}$ & $\begin{array}{c}0.023 \\
(0.070)\end{array}$ & $\begin{array}{c}0.030 \\
(0.070)\end{array}$ & $\begin{array}{c}0.418 * * * \\
(0.102)\end{array}$ & $\begin{array}{c}0.411 * * * \\
(0.097)\end{array}$ & $\begin{array}{c}0.443 * * * \\
(0.139)\end{array}$ & $\begin{array}{l}-0.035 \\
(0.158)\end{array}$ & $\begin{array}{c}0.081 \\
(0.062)\end{array}$ & $\begin{array}{c}0.060 \\
(0.120)\end{array}$ \\
\hline Output gap & $\begin{array}{c}-0.093 \\
(0.071)\end{array}$ & $\begin{array}{l}-0.106 \\
(0.091)\end{array}$ & $\begin{array}{l}-0.107 \\
(0.091)\end{array}$ & $\begin{array}{c}0.033 \\
(0.036)\end{array}$ & $\begin{array}{c}0.030 \\
(0.033)\end{array}$ & $\begin{array}{c}0.015 \\
(0.027)\end{array}$ & $\begin{array}{l}-0.164 \\
(0.171)\end{array}$ & $\begin{array}{l}-0.241 \\
(0.250)\end{array}$ & $\begin{array}{l}-0.247 \\
(0.277)\end{array}$ \\
\hline Exchange rate change & & $\begin{array}{c}0.323 * * \\
(0.137)\end{array}$ & $\begin{array}{c}0.326^{* *} \\
(0.137)\end{array}$ & & $\begin{array}{c}0.010 \\
(0.016)\end{array}$ & $\begin{array}{c}0.031 \\
(0.027)\end{array}$ & & $\begin{array}{c}0.587 * * * \\
(0.085)\end{array}$ & $\begin{array}{c}0.563 * * * \\
(0.033)\end{array}$ \\
\hline Crisis dummy & & & $\begin{array}{l}-0.302 \\
(0.202)\end{array}$ & & & $\begin{array}{l}-1.158 \\
(1.421)\end{array}$ & & & $\begin{array}{c}3.601 \\
(14.959)\end{array}$ \\
\hline Constant & $\begin{array}{c}0.662 * * \\
(0.323)\end{array}$ & $\begin{array}{c}1.524 \\
(0.956)\end{array}$ & $\begin{array}{c}1.558 \\
(0.957)\end{array}$ & $\begin{array}{l}-0.132 \\
(0.309)\end{array}$ & $\begin{array}{l}-0.150 \\
(0.282)\end{array}$ & $\begin{array}{c}0.046 \\
(0.316)\end{array}$ & $\begin{array}{c}1.077 \\
(0.680)\end{array}$ & $\begin{array}{c}3.509 * * * \\
(1.297)\end{array}$ & $\begin{array}{c}3.220 * * * \\
(0.788)\end{array}$ \\
\hline Observations & 1257 & 1257 & 1257 & 507 & 507 & 507 & 750 & 750 & 750 \\
\hline Countries & 24 & 24 & 24 & 9 & 9 & 9 & 15 & 15 & 15 \\
\hline No. Instruments & 22 & 21 & 22 & 7 & 9 & 9 & 13 & 13 & 13 \\
\hline $\mathrm{AB}(2)$ & -1.641 & -1.041 & -1.047 & -1.971 & -1.914 & -2.034 & -1.706 & -0.592 & -0.684 \\
\hline p-value & {$[0.101]$} & {$[0.298]$} & {$[0.295]$} & [0.049] & {$[0.056]$} & {$[0.042]$} & {$[0.088]$} & {$[0.554]$} & {$[0.494]$} \\
\hline $\begin{array}{l}\text { Hansen } \\
\text { p-value }\end{array}$ & $\begin{array}{l}21.203 \\
{[0.269]}\end{array}$ & $\begin{array}{l}18.291 \\
{[0.307]}\end{array}$ & $\begin{array}{l}18.516 \\
{[0.295]}\end{array}$ & $\begin{array}{c}1.698 \\
{[0.637]}\end{array}$ & $\begin{array}{c}3.482 \\
{[0.481]}\end{array}$ & $\begin{array}{c}1.747 \\
{[0.627]}\end{array}$ & $\begin{array}{c}10.894 \\
{[0.283]}\end{array}$ & $\begin{array}{c}12.372 \\
{[0.135]}\end{array}$ & $\begin{array}{l}10.123 \\
{[0.182]}\end{array}$ \\
\hline
\end{tabular}

Notes: see Table 3. 
Table 5. SGMM Results. Sample partition: before and after the financial crisis.

\begin{tabular}{lcccccc}
\hline Variables & \multicolumn{3}{c}{ Before Crisis } & \multicolumn{3}{c}{ After Crisis } \\
\cline { 2 - 7 } & $(1)$ & $(2)$ & $(3)$ & $(4)$ & $(5)$ & $(6)$ \\
\hline \multirow{2}{*}{ Lagged interest rate } & $0.482^{* * *}$ & $0.479^{* * *}$ & $0.479^{* * *}$ & $0.862^{* * *}$ & $0.864^{* * *}$ & $0.863^{* * *}$ \\
& $(0.137)$ & $(0.136)$ & $(0.120)$ & $(0.038)$ & $(0.037)$ & $(0.037)$ \\
Inflation & $0.130^{* *}$ & $0.136^{* *}$ & 0.119 & $0.123^{* * *}$ & $0.124^{* * *}$ & $0.122^{* * *}$ \\
& $(0.065)$ & $(0.064)$ & $(0.075)$ & $(0.034)$ & $(0.034)$ & $(0.034)$ \\
Output gap & -0.138 & -0.135 & -0.151 & -0.001 & -0.001 & -0.001 \\
& $(0.130)$ & $(0.129)$ & $(0.135)$ & $(0.008)$ & $(0.008)$ & $(0.008)$ \\
Exchange rate change & $0.561^{* * *}$ & $0.560^{* * *}$ & $0.587 * * *$ & 0.011 & 0.010 & 0.021 \\
& $(0.094)$ & $(0.095)$ & $(0.062)$ & $(0.013)$ & $(0.012)$ & $(0.045)$ \\
IT dummy (dIT) & & 0.977 & 0.860 & & 0.044 & 0.045 \\
& & $(0.838)$ & $(0.923)$ & & $(0.125)$ & $(0.133)$ \\
Exchange rate change * dIT & \multicolumn{7}{c}{$-0.464 * * *$} & & & -0.012 \\
& & & $(0.179)$ & & & $(0.043)$ \\
Constant & $3.335^{* * *}$ & $2.953 * *$ & $3.029 * * *$ & 0.096 & 0.067 & 0.076 \\
& $(1.244)$ & $(1.193)$ & $(1.113)$ & $(0.142)$ & $(0.161)$ & $(0.170)$ \\
Obs. & & & & & & \\
N & 652 & 652 & 652 & 605 & 605 & 605 \\
No. Instruments & 23 & 23 & 23 & 24 & 24 & 24 \\
AB(2) & 21 & 22 & 22 & 21 & 22 & 23 \\
$\quad$ p-value & -0.557 & -0.563 & -0.590 & -0.187 & -0.184 & -0.199 \\
Hansen & {$[0.577]$} & {$[0.573]$} & {$[0.556]$} & {$[0.852]$} & {$[0.854]$} & {$[0.842]$} \\
$\quad$ p-value & 19.442 & 19.260 & 19.126 & 20.141 & 20.093 & 20.325 \\
Notes: see Table 3. & {$[0.246]$} & {$[0.255]$} & {$[0.262]$} & {$[0.214]$} & {$[0.216]$} & {$[0.206]$} \\
\hline
\end{tabular}

